\title{
ON THE FORMS AND THORNS OF LINGUISTIC INDETERMINACY IN CHINESE LAW
}

\section{MICHELE MANNONI, PhD}

\author{
Department of Foreign Languages and Literature \\ University of Verona, Italy \\ Polo Zanotto - Viale Università, 4 - 37129 Verona, Italy \\ michele.mannoni@univr.it - mi.mannoni@gmail.com
}

ORCID: https://orcid.org/0000-0002-8816-3757

\begin{abstract}
This study addresses the different types and implications of linguistic indeterminacy in Chinese law. It firstly draws on the studies of scholars of different disciplines, such as linguistics and philosophy of language, to provide a taxonomy of indeterminacy in language. It then provides examples of each type, highlighting the implications in law and legal interpretation. It uses linguistic data from various texts, such as statutory laws and judgements, and analyses them with various methods, including discourse analysis and corpus linguistics. This study argues that when the language of the law is indeterminate, the legal outcomes may be particularly uncertain. It suggests that although it is difficult to ascertain whether the degree of indeterminacy is higher in some languages more than in others, some linguistic mechanisms at the word-formation level in Chinese, such as portmanteaus and the modifier-
\end{abstract}


modified structure, are remarkably ambiguous. When uncertain terms are in key parts of the law, the consequences may be more serious. The study of linguistic indeterminacy in Chinese has implications for the study of forensic linguistics, and Chinese studies in general.

Key words: Linguistic vagueness; linguistic ambiguity; Chinese law; Chinese legal language; cross-lingual studies

\title{
论中国法律中语言不确定性的形式与苦惱
}

摘要: 本篇文章浅析中国法律中语言不确定性(linguistic indeterminacy)的 各种类型及其在法律方面的影响。首先, 笔者借鉴了语言学和语言哲学 等不同研究方向的学者的研究对语言不确定性进行分类。其次, 对每种 类型提供了例子和阐述, 并着重阐述法律中语言不确定性与法律和法律 解释的关系。本研究里所使用的数据主要来自成文法和判决书, 并对其 通过不同方法进行了分析, 包括语料库语言学分析和话语分析。笔者认 为, 当法律的语言不确定时, 法律结果也会随之变得不确定。尽管很难 判断某种语言中的不确定性程度是否同其他语言的一样, 本研究却显示, 中文里构词的一些方式(例如混成词和定语-中心语)所致使的语义却尤其 含糊不清。若法律的矢键部分存在着语言不确定性, 其影响会更加严重。 中文里的语言不确定性研究, 对法律语言学以及整个中国研究都有启示。

矣键词: 语言的模糊性; 语言歧义; 中国法律 ; 中文法律语言 ; 跨语言 研究

\section{FORME E TORMENTI DELL'INDETERMINATEZZA LINGUISTICA NEL DIRITTO CINESE}

\begin{abstract}
Il presente studio si propone di indagare le diverse tipologie e le implicazioni dell'indeterminatezza linguistica nel diritto cinese. Dapprima forniamo una tassonomia dell'indeterminatezza linguistica sulla base di alcuni studi afferenti alle principali aree di ricerca in cui il tema è stato tradizionalmente trattato, quali la linguistica e la filosofia del linguaggio. Per ciascuna delle categorie tassonomiche individuate vengono poi forniti alcuni esempi di modo da sottolineare le implicazioni per il diritto e per l'interpretazione giuridica. I dati linguistici utilizzati ai fini di questo studio sono stati tratti da diversi testi, tra cui sentenze e testi normativi, e sono stati analizzati con vari metodi, tra cui quelli propri dell'analisi del discorso e della linguistica dei corpora. Lo studio sostiene l'esistenza di una correlazione tra incertezza del linguaggio e incertezza del diritto. Sostiene inoltre che nonostante sussista una generale difficoltà nello stabilire se il grado di indeterminatezza sia più alto in alcune lingue rispetto ad altre, in cinese, per esempio, alcuni meccanismi nella formazione del lessico, tra cui parole
\end{abstract}


macedonia e il costrutto determinante-determinato, sono particolarmente ambigui. Quando punti chiave di norme giuridiche presentano un lessico indeterminato, le conseguenze giuridiche possono essere particolarmente significative. Lo studio dell'indeterminatezza linguistica del cinese può contribuire allo studio della linguistica forense e della sinologia in generale.

Keyword: Vaghezza linguistica; ambiguità; diritto cinese; linguaggio giuridico cinese; studi interlinguistici

\section{Acknowledgements}

The Author wishes to acknowledge the funding granted to the Department of Foreign Languages and Literature at the University of Verona by the Italian Ministry of Education, University and Research (MIUR) under the "Departments of Excellence" plan for the project "Digital Humanities Applied to Foreign Languages and Literatures" (2018-2022). The two anonymous reviewers are also acknowledged for their insightful remarks.

\section{Introduction}

On March 1, 2016, China enacted its first national law against domestic violence (2016). In Article 37, the law stipulates to safeguard any victims of domestic violence besides family members, including those who live together (gongtong shenghuo 共同生活) ${ }^{1}$. It was thought at first that by using such a vague wording, China was implicitly recognising homosexual co-habiting families. It was not. Even though that same legal term may include gay couples in some societies, the Chinese authorities provided a more restrictive interpretation. This kind of intralingual indeterminacy in the Chinese legal terminology is not rare and has legal implications. When the Chinese statutes or the legal documents drawing from them are translated into other languages, interlingual indeterminacy arises, making the original uncertainty of some terms even more evident, or making terms that were not uncertain at first become so.

This study addresses the different types and implications of linguistic indeterminacy in Chinese law. It firstly draws on the studies of scholars of different disciplines, such as linguistics and philosophy of language, to provide a taxonomy of indeterminacy in language. It

\footnotetext{
${ }^{1}$ See D'Attoma (forthcoming) for a discussion on the legal aspects of this provision.
} 
then provides examples of each type, highlighting the implications in law and legal interpretation. It uses linguistic data from various texts, such as statutory laws and judgements, and analyse them with various methods, including discourse analysis and corpus linguistics. This study argues that when the language of the law is indeterminate, the legal outcomes may be particularly uncertain. It holds that some linguistic mechanisms at the word-formation level in Chinese are especially ambiguous. When uncertain terms are in key parts of the law, the consequences may be more serious. The study of linguistic indeterminacy in Chinese has implications for the study of forensic linguistics, and Chinese studies in general.

\section{On the forms of linguistic indeterminacy}

Following Cao (2007a:70), in this study I use "indeterminacy" interchangeably with the term "uncertainty" to cover any indeterminacy of language, including vagueness, generality, and ambiguity (see also Chang 1999). As has been pointed out, uncertainty is part and parcel of language and law and cannot be avoided. It has been said to be functional to law, to be detrimental to law, or to have no function at all in law (Asgeirsson 2015; Simonnæs 2007; Waldron 2011; Schneider 2007; Schane 2002). Such different opinions notwithstanding, it is ubiquitous in any natural language, as well as in many specialised languages, including the language of the law (Endicott 2000), where precision and clarity has been traditionally and popularly expected. In legal practice, legal disputes are often caused by real or allegedly different interpretations of one term, phrase, or syntactic structure (Shuy 2008; Triebel 2009: 154; Schane 2002), and they may lead to different verdicts, and different punishments. The legal position of one may change depending on the uncertain language used about or by them, as may happen in statutes and private documents. When legal texts are translated into another language, for private legal purposes or for the purposes of multilingual jurisdictions, the legal translator may be prompted to face uncertainty about the legal meaning of a term or wording. As said, this latter type of indeterminacy is called interlingual indeterminacy.

Different authors propose different classifications of uncertainty and vagueness, sometimes making a distinction between the 
two. The taxonomy I propose in this study includes the instances of scholars from various disciplines, such as linguistics and philosophy of language in which uncertainty, and especially vagueness, has been theoretically addressed. It is aimed at showing that there are various types of uncertainty, and that they require different solutions. It also serves as a caveat not to extend any of the statements in this study to any other types of uncertainty rather than to the ones they are specifically intended for.

The structure of my taxonomy is outlined in Table 1 below and is described in greater detail hereafter:

\section{Table 1: Taxonomy of Intralingual Indeterminacy}

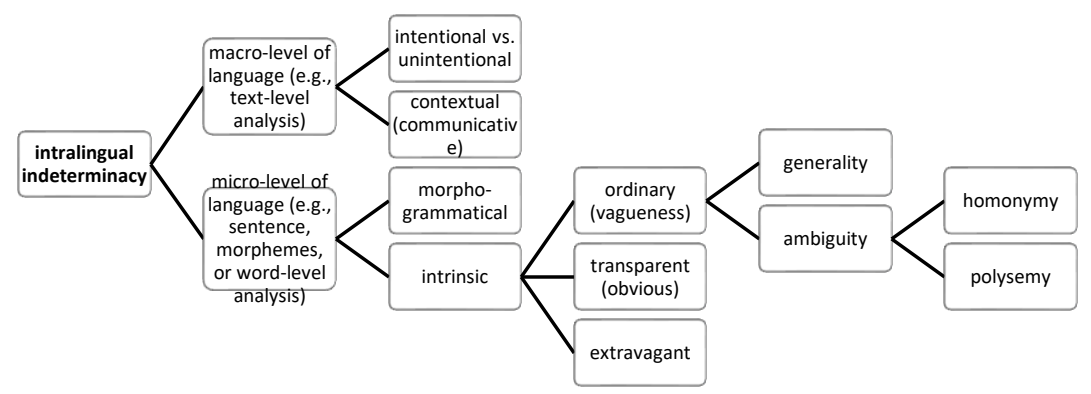

At the macro-level of language, i.e. the level at which we analyse an entire text rather than smaller units such as words or morphemes, there is intentional vs. unintentional indeterminacy, and contextual indeterminacy. At the micro-level of language there is grammatical indeterminacy, and intrinsic indeterminacy, which occurs at the word level. It is noted that since the composition of Chinese words largely reflects the Chinese syntax, grammatical indeterminacy in Chinese includes morphological uncertainty, and can be termed morpho-grammatical indeterminacy. This will be illustrated in the next section. Although the different types of linguistic indeterminacy I am presenting here display distinct features, they are also relative, and may sometimes overlap or co-exist (Cao 2007a: 70). 


\section{Michele Mannoni: On the Forms and Thorns of Linguistic...}

With respect to the intention of the producer of a text (whether written or spoken) towards their text, we can distinguish two types of indeterminacy in language, i.e. intentional vs. unintentional indeterminacy. As the names suggest, the first is determined by the speaker's intent to purposely speak vaguely. For instance, intentional indeterminacy has been found in deceptive ambiguity used by police or prosecutors (Shuy 2017), or when the uncertain meaning of a term is intentionally used as a form of negotiation to paper over the fact that the parties or the legislators had conflicting views and have not reached a sound agreement (Cao 2007a: 71; Marmor 2014: 97). Importantly, intentional uncertainty is part and parcel of the speaker's message and has to be preserved in translation. As we will see, the same does not go for unintentional uncertainty, which needs to be solved in interlingual translation if the target language so requires. This level of analysis includes the further types of indeterminacy that we find at the microlevel of analysis.

In communicative uncertainty, the speaker's words may not necessarily be vague, but the speaker's communicative attitude is, whether intentionally (Keil and Poscher 2016: 6) or not (Marmor 2014: 91). This type of indeterminacy is a form of underspecification (Keil and Poscher 2016: 7) and is contextual (Marmor 2014: 90-91). One phrasing can be deemed as sufficiently clear in one context, but unclear in another. This study will show that besides non-technical words with ordinary meanings, and legal words with technical legal meanings (Cao 2007a: 73), another source of uncertainty in the Chinese law is ordinary words with legal meanings, being clear in ordinary language, but unclear in the legal context. This is a recurrent source of interlingual indeterminacy for the translator who translates the Chinese legal language.

Morpho-grammatical indeterminacy is the uncertainty arising from the way words are composed or arranged in a sentence. It is common in Chinese legal language. Various reasons have been identified for this, including that Chinese characters are more like root words or morphemes than words (Cao 2018a: 150). Additionally, Chinese is a prototypical analytic language: it has no inflection, no gender, no number, and the semantic relationship between the morphemes of a word is largely opaque. Due to the intrinsic linguistic features of the Chinese language, grammatical uncertainty in Chinese is often unintentional. When ascertaining the meaning of many Chinese words, the translator needs to arbitrarily attribute grammatical markers, 
such as gender, number, or verb tense, to a word. As we will see in the following section, a semantically obscure modifier-modified structure occurs in the Chinese legal lexicon, and it cannot be maintained as implicit in translation. The resulting translation of a lexical item into any less analytic and more explicit target language will, therefore, necessarily be less uncertain than in Chinese.

In intrinsic uncertainty, the speaker's words or terms are inherently indeterminate, regardless of the context. Drawing from Marmor (2014)'s taxonomy, we can identify three sub-types of intrinsic uncertainty: ordinary uncertainty, transparent (or obvious) uncertainty, and extravagant uncertainty (a term coined by Endicott, cited in Marmor 2014: 88). It is noted that Marmor's classification addresses vagueness rather than uncertainty. As said, vagueness can be considered a subtype of uncertainty, as Cao's maintains (2007a). In fact, as Marmor's examples of vagueness are analogous to those made by Cao, I include Marmor's taxonomy for vagueness within the broader category of uncertainty and indeterminacy.

A word is ordinarily uncertain if its indeterminacy is not manifest and evident, yet when we are prompted to state whether its meaning includes an entity or a concept, we cannot say for sure, and we realise that its meaning is uncertain. This definition is sometimes similarly used for vagueness (e.g. Antia 2007: xv), although Simonnæs holds that "vagueness is a property of concepts", rather than words (2007: 22). Ordinary uncertainty includes the sub-types of generality and ambiguity. A general word is one that refers to "any one of a number of things whose differences are not denied or necessarily overlooked" (Cao 2007a: 70). An oft-quoted example is H L A Hart (2012: 126)'s word 'vehicle' (cf. Marmor 2014: 92). If a city ordinance stipulates that no vehicle is allowed in the park, entrance is very likely to be forbidden to motor vehicles; but are bikes or skateboards also forbidden? This type of indeterminacy is frequent in law but is not evident. A term is ambiguous when it has more than one possible meaning. Ambiguity thus includes homonymy and polysemy (see Andersen (2002)'s taxonomy, used by Rogers 2007: 17). As we will see hereafter, some of the Chinese key legal terms are ordinarily uncertain.

Obvious (transparent; Marmor, 2014) uncertainty is easier to observe. Obviously vague words imply a sorites sequence, that is to say, they have a fictitious minimum and a maximum point, but there is no clear cut-off point in between (cf. Alston 1964: 87-8). In law, they may be a complication and lead to legal disputes. 
The third type of intrinsic uncertainty is even more obvious, but more complex - it is, thus, extravagant (Endicott 2011: 24-5). As Marmor notes (2014: 89), its main feature "consists in the fact that they designate a multidimensional evaluation with (at least some) incommensurable constitutive elements." Law is packed with extravagantly uncertain words. Legal terms such as "reasonable", "fair", "just", "legitimate", "prudent", "cruel and unusual", etc. are frequent in law and they are extravagantly uncertain.

The degree of indeterminacy may not be the same in every language. Some scholars maintain that one language may be more uncertain than another (but see Balley 1944, in Cao 2007a: 81 for an opposite thesis). Chinese has been said to be vague, and vaguer than other languages, such as English (Cao 2004; 2018a; but cf. Triebel 2009). Due to the quantitative nature of the question as to whether one language can or cannot be said to have a higher degree of indeterminacy than another language, it is acknowledged that it takes extensive comparative quantitative data to answer the question. This is not my aim here, although, whenever possible, I offered statistical indications about my data, with an eye to prompting quantitative research in the field. When two languages are considered and compared, such as in bilingual law and legal translation, intralingual uncertainty becomes especially visible. When crossing two languages as in bilingual legislation, and two legal systems and cultures as in translation, translators are prompted to face uncertainty. This further type of indeterminacy has been termed interlingual uncertainty (Cao 2007a).

\section{On the thorns of linguistic indeterminacy}

To illustrate the foregoing taxonomy, we can use empirical linguistic data from legal texts of various kinds, such as statutes and court decisions. For the purposes of this study, these texts were found in different databases. As to Chinese statutes, they can be accessed online at different Chinese governmental websites such as the Digital Repository of Laws and Regulations and The Central People's Government of the People's Republic of China. The laws and regulations of China have also been collected and stored in a corpus (hereinafter ChinLaw) created at the University of Verona under the "Departments of Excellence" plan granted to the Department of Foreign 
Languages and Literature for the project "Digital Humanities Applied to Foreign Languages and Literatures" (2018-2022). The ChinLaw corpus so far counts around 1.5 million tokens and 466 statutes of the People's Republic of China with the exclusion of territorial entities where different laws are in force, such as Macau and Hong Kong.

From the perspective of corpus search methodology, it is noted that, at present, there is no way to access linguistic data such as that in a corpus from general rules (Deignan 2005: 92), thus one cannot search for indeterminate wordings, by say, inserting "vague words" or similar keywords in a search box. Two approaches are instead possible: bottom-up, i.e. from words to observation, and top-down, i.e. from our prediction about language to words. I took both approaches in this study. In the first, I used various methods of corpus search, such as identification of the most frequent words and collocates to then make considerations about them. In the second, I searched for wordings that I presumed to be indeterminate, and then verified whether they in fact were in my data and discussed them accordingly. Relevantly, it is acknowledged that, as noted by Sinclair, people's intuition about impressions of language is largely unreliable and shows significant differences between the data retrieved objectively from texts (1999: 178). This is why corpus linguistics is particularly useful, for it enables the researcher to confirm or disprove their intuitions. As is known, corpus linguistics has been significantly garnering legitimacy in forensic studies and practice (Volokh 2015; Solan and Tammy 2016; Marmor 2014: 93). These methods are illustrated in greater detail in the next section, where they are used. The corpus software I used is LancsBox, developed at Lancaster University by Brezina, Timperley, and McEnery (2018).

As to court decisions, a few years ago the Chinese government began to upload them to a public database called China Judgements Online (hereinafter CJO), containing around 92 million court decisions from China as of the time of this writing. The databank makes it possible to look for judgments by keywords. So, by inputting a word such as, say, cheliang 车辆 ('vehicle') in a search box, the system retrieves all the court decisions including that word.

In the following subsections I am going to illustrate the various forms of linguistic indeterminacy by retrieving examples using the methods I have just described. 


\subsection{Intentional vs. unintentional indeterminacy}

Starting from the macro-level of language analysis, there is, as said, intentional vs. unintentional indeterminacy, and contextual indeterminacy.

The first aspect to observe is that it may be complex to determine if a wording has been willingly used in an indeterminate fashion. We need to either rely on an honest declaration by the producer of the uncertain wording, such as a layperson in the case of private legal documents or court depositions, or that of a government representor in the case of nationally enacted laws. In the absence of such a declaration, we may try to determine whether the linguistic indeterminacy was deliberate basing on context. The same is done by the judge before whom a case of linguistic indeterminacy is argued.

Intentional indeterminacy in law appears when someone wants to achieve a purpose by using uncertain language. When there is an intention to speak or write vaguely, there is an end one aims to reach. This is true for the lawmakers, and for the single individuals who are the subject of the law. As has been noted in the philosophy of legal language, indeterminacy is purposeful to law (Simonnæs 2007), as, inter alia, it ensures that one broad theoretical principle is applied to an indefinite number of concrete matters. In the court process, a litigant or a witness may be intentionally vague in order to hide the truth from the judge. This is termed reticence and is a crime under many jurisdictions. As said, in bilateral agreements, whether at the national or international governmental level, intentional indeterminacy has been observed to be used to paper over the fact that the parties have not reached a sound agreement (Cao 2007a: 71). The same applies to private agreements: by resorting to linguistic indeterminacy, the parties can include their contrasting views under one general phrasing, while nonetheless reaching a more general objective. When one party proposes a vague phrasing in the contract drafting without the other party being aware of the possible implications, the contract is more likely to privilege the party who proposed the phrasing. Many jurisdictions based on Western law around the world have specific provisions regulating this case, in order to protect the party who has not proposed the indeterminate clause. This is a doctrine of contractual interpretation, termed contra proferentem in Latin, or "interpretation against the draftsman" in English. This doctrine provides that the language of a contract should 
be interpreted against the party who caused the uncertainty to exist, as indicated in Article 41 of the Contract Law of China, which transplanted the doctrine from the West (Fu 2011: 82) (cf. e.g. Article 1370 of the Civil Code of Italy) (any English translation in this paper is my own):

\section{“第四十一条【…】对格式条款有两种以上解释的, 应当作出不 利于提供格式条款一方的解释【…】}

Article 41. [...] If one clause has two or more possible interpretations, it should be interpreted against the interest of the drafter [...]."

Intentional indeterminacy is thus connected to the concept of will, which plays a key role in law. Once one has found what the intention behind the wilful indeterminacy is, any legal deed can be interpreted and regulated accordingly. I will provide other examples of intentional uncertainty in the following analysis, showing the legal effects that it can have, and contrast it with unintentional uncertainty.

To illustrate unintentional indeterminacy, we can use Article 37 of the Domestic Violence Law (2016; my emphasis), mentioned at the beginning of this study:

\section{“第三十七条 家庭成员以外共同生活的人之间实施的暴力行为, 参照本法规定执行。}

Article 37 Any violent act between any persons who live together besides family members is regulated by the provisions of this law."

As said, when the law was publicly announced, many Chinese and foreign people thought that China was intentionally using an equivocal wording such as "any persons who live together" (gongtong shenghuo de ren) to include any persons who actually live together, regardless of their sexual orientation and genders. The legal meaning of the phrasing had to be publicly clarified by the authorities in a public press conference right after the Plenary Meeting that passed the law had finished. As reported by The Observer, Mr Guo Linmao (郭林茂), responsible person of the Social Law Department of the Plenary Meeting, replied as follows to a journalist of the Associated Press, the American first national press agency: 


\begin{abstract}
“美联社记者：矢于反家庭暴力法当中的第 37 条, 家庭成员以外 共同生活人实施的暴行。我想问一下, 在这个定义当中, 包括不 包括同性恋的居住者? 谢谢。
\end{abstract}

\title{
社会法室负责人郭林茂：【...】我前面说了, 我们这种家庭成员 之外共同生活的人，包括监护、寄养、同居生活的，但是对同性 恋的到现在我们的法律没有规定，也没有这个事情。谢谢。
}

Journalist of APTN: "I'd like to ask you if the phrase "violent act between any persons who live besides family members' as used in Article 37 of the Law Against Domestic Violence includes same-sex cohabitants or not. Thank you."

Lin Mao, responsible person of the Social Law Department of the Plenary Meeting: "[...] As I've said earlier, our 'anyone who live together besides family members' includes guardianship, foster care, people living together, but as to same-sex couples, as of today, our law has no provisions, and there is no such thing. Thank you."'

(He Shurui (ed.), 2015; my emphasis)

As can be seen, the authority declared that same-sex couples were not protected by the newly enacted law, as the way they intended the indeterminate wording differed substantially from its contextual meaning in ordinary language. This is understood from the use of the possessive adjective women (我们), meaning 'our', used by Mr Guo in the above excerpt. In other words, by using this adjective, the spokesman confirmed that the indeterminacy was contextual and unintentional, being that a wording that includes anyone who lives under the same roof in ordinary language, but that has a much narrower interpretation in the law against domestic violence.

Additionally, in clarifying the meaning of the uncertain words in the law, Mr Guo used other phrasings whose meaning was unclear nonetheless: for instance, he used the term tongju shenghuo that similarly means 'people living together' to explain the meaning of the other uncertain phrasing, thus creating confusion between two seemingly synonymic terms (i.e., gongtong shenghuo and tongju shenghuo, both meaning 'to live together'). In fact, neither of them is useful to clarify the other. He also used the ambiguous phrase 'there is no such thing': What does 'there is no such thing' mean? There is no such thing as same-sex couples? Or there is no such a thing as violence between same-sex couples? Whichever the case, in clarifying the unintentional and contextual linguistic indeterminacy of the law, the 
Chinese government spokesperson used other vague phrasings, suggesting a general embarrassment about the question, or that the topic was sensitive, and no further indications could be given as of that time.

In the next parts of this study, we will notice that when the topic is sensitive, uncertainty is in fact more likely to be found. We will also see other examples of unintentional and intentional indeterminacy, since, as said, this macro-level of analysis is reflected at the word-level.

\subsection{Morpho-grammatical uncertainty}

At the micro-level of analysis, there is morpho-grammatical indeterminacy and intrinsic indeterminacy. We shall begin by looking at the first of these types.

Morpho-grammatical indeterminacy is especially present in Chinese, due to many linguistic factors that are unique to the Chinese language. Chinese is the prototype of analytic language, so words generally have no number, no gender, and no verb tense indication, as Cao points out (2018a: 150-1). Additionally, Chinese characters are not words in the strict English sense, but they resemble more root words or morphemes than words. They can combine in different orders and in different words almost like morphemes do, and from their broad meanings uncertainty originates (see also Wong, Li, and Xu 2009: $37-$ 8). Two phenomena of morpho-grammatical uncertainty in Chinese have not been addressed explicitly by scholarship and deserve our attention: linguistic blends (aka portmanteaus) in contrast to compound words, and the modifier-modified structure.

A linguistic blend or portmanteau consists in the fusion of different parts of words into one new word. Examples of portmanteaus in English are the words "smog" and "netizen", being the fusion of smoke $+\mathrm{fog}$, and internet + citizen, respectively. Linguistic blends are present in many languages, but are pervasive in the Chinese language, including the legal language. The more formal the register, the more portmanteaus we find. As formal Chinese tends to be extremely concise, abbreviated forms of wordings are preferred. For instance, instead of zhe bu falü (这部法律, 'this law'), four syllables, one finds ben fa (本 法), two syllables that mean the same. The portmanteau resulting from the blend of two disyllabic words can have any of the following 
structures in Chinese (in the following scheme, each capital letter indicates a syllable):
(1) $\underline{\mathrm{AB}}+\underline{\mathrm{CD}}=\mathrm{AC}$
(2) $\underline{A B}+C \underline{C D}=A D$
(3) $\mathrm{A} \underline{B}+\underline{C D}=\mathrm{BC}$
(4) $\mathrm{A} \underline{B}+\underline{C} \underline{D}=B D$

The above combinations may not be equally possible, some being more frequent than the others. In true portmanteaus, the parts of the words blended in the new word maintain the meaning of the words each of them stand for. Reversely, in compound words each component has an independent meaning. For instance, in the English portmanteau "netizen", net- stands for internet, and -izen for citizen. Conversely, in the compound word "fireman", "fire" actually means "fire", and "man" means "man". Since Chinese does not have letters, but characters, each character generally represents a syllable and a morpheme. The vast majority of disyllabic words consists in two morphemes. Hence, the uncertainty arises as to how to interpret a disyllabic word; one may well wonder, Is it a portmanteau, or a compound word? Uncertainty arises because one cannot be sure if the disyllable is in fact a portmanteau, whose meaning is that of the two words it stands for, or a compound word, whose meaning is that resulting from the combination of its morphemes. In other words, when finding, say, AD as in (2) above, the question is: Is $A D$ a new word with an independent meaning, or has $A D$ the meaning of $A B+C D$ ?

To illustrate we can use the term quanyi (权益), which is often translated as 'rights and interests': for instance, the Xiaofeizhe Quanyi Baohufa 消费者权益保护费 is translated by the Ministry of Commerce of China as "Law on the Protection of the Rights and Interests of Consumers". The term appears in various legal wordings, such as hefa quanyi (合法权益, 'lawful rights and interests'), zhengdang quanyi (正 当权益, 'proper rights and interests') and, intriguingly, feifa quanyi (非 法权益, 'illegal rights and interests') (Cao and Mannoni 2017; Mannoni 2018; Mannoni and Cao 2018; Mannoni 2019). Under the portmanteau interpretation, quanyi is the short form of quanli he liyi (权 利和利益, 'rights and interests'), a phrase appearing in many legal texts, including Article 50 of the Constitution. In the phrase quanli he liyi, the two identical syllables $l i$ and the conjunction he ('and') are removed for brevity, hence we find quanyi. This follows the tendency exemplified 
in (2) (i.e., $\underline{A B}+C \underline{D}=A D$ ). Reversely, under the compound word interpretation, quanyi would be a specific notion, and a different word to quanli he liyi 'rights and interests.'

From the legal perspective, these two interpretations have been shown to be equally possible, but have different implications (Benney 2013: 42-3; Mannoni 2018). Under the first "portmanteau" interpretation, quanyi is 'rights and interests', with the correspondent legal notions of rights and interests having a major role in the Roman and German tradition, under which systems, rights are lawful by definition. If it is illegal, it cannot be a right. Consequently, a phrasing such as feifa quanyi 'illegal rights and interests', appearing at the time of this writing in 924 court decisions in the CJO database (i.e. 807 more than in a 2017 study conducted by Cao and Mannoni 2017), would be a strong oxymoron. Benney (2013: 42-3) seems to plead for the wordcompound interpretation, as he argues that quanyi is a notion weaker and more alienable than ordinary rights. As said, both interpretations are plausible: in the first, we can use the Sapir-Whorfian hypothesis (Hoijer 1954) to interpret the wording, and argue that feifa quanyi indicates that rights in China, i.e. Chinese rights, are not equal to Western rights. This has implications for the debated concept of universality of rights: Is there such a thing as universal rights if the very notion of right has no traces in some countries, such as ancient China (cf. Cao 2017)? In the second, feifa quanyi is to be interpreted with quanyi as a compound word, and translated with a neologism, or a loan word such as 'illegal quanyi' - obscure as this may sound. As can be seen, when two languages are contrasted, such as in legal translation, intralingual indeterminacy may result in interlingual indeterminacy.

The other phenomenon of morpho-grammatical uncertainty is the modifier-modified structure, which is reflected in the relationship between the component of compound words. In this regard, it has to be noted that Chinese word formation largely reflects that of Chinese grammar. For instance, Chinese is an SVO language; accordingly, at the word formation level, the word for "to legislate" is lifa (立法), literally 'to create + law', a VO compound. Similarly, in Chinese syntax, the modifier comes ahead of the modified; accordingly, the word for “cold war” is lengzhan (冷战), literally 'cold + war', with 'cold' being an adjective modifying, and thus coming ahead of the word for 'war'. This modifier-modified structure is especially difficult to make meaning of, because it is highly implicit and contextual. It is, thus, a source of linguistic indeterminacy. In their famous work on Mandarin 
Chinese grammar, Li and Thompson (1989: 48-53) identified twentyone types of semantic relationships between the components of a word compound, some of them being applicable to the modifier-modified structure. For instance, in a $\mathrm{N}_{1} \mathrm{~N}_{2}$ structure (where $\mathrm{N}$ indicates a noun), $\mathrm{N}_{1}$ may denote the place where $\mathrm{N}_{2}$ is located, or the material of which $\mathrm{N}_{1}$ is made, or a place where $\mathrm{N}_{1}$ is sold, or a person who sells or delivers $\mathrm{N}_{1}$, etc. (Li and Thompson 1989: 48-53). There is no certainty as to how $\mathrm{N}_{1}$ semantically connects to $\mathrm{N}_{2}$. This complicates meaning making in the Chinese language of the law.

To illustrate the semantic complications of the modifiermodified structure, we can go back to the feifa quanyi term: Are the 'rights and interests' or 'quanyi' illegal in nature? Or does the modifier 'feifa' indicate something different about the modified? For instance, Cao and Mannoni (2017) have pointed out that the modifier-modified structure in the term may imply a causal relationship. Under this interpretation, feifa quanyi is not 'illegal rights and interests/quanyi', but 'rights and interests obtained through illegal means'. In a decision made by the Supreme People's Court in 2018, the justice affirmed the following:

\section{“孙 $[. .$.$] 系先建房，然后通过伪造户籍资料等方式骗取《集体土地$ 使用证》，其权益并不是株洲县政府的授益性行为而产生，而是 想通过非法手段使其非法权益披上合法外衣，不应当受到法律保 护。}

$\mathrm{Mr} / \mathrm{s}$ Sun $[\ldots]$ is the one who first built the construction, and then by various means, such as falsification of residence documents, falsely obtained a permit to use the collective land. Her/his quanyi are not the result of an award of benefits from the County Government of Zhengzhou, but of his/her use of unlawful means to cover his unlawful quanyi with a lawful veil. As such, the law does not protect them."

(Decision no. 3528 of the Supreme People's Court ${ }^{2}$. Available at CJO, accessed May 27, 2020; my emphasis)

As can be seen, the rights and interests argued in this case are in fact obtained through illegal means, and the court decided not to protect them. From the legal perspective, this creates legal uncertainty: how

\footnotetext{
${ }^{2}$ Chinese title and number of the cited court decision: 頪洲县人民政府、孙伏良资源 行政管理:土地行政管理(土地)再审审查与审判监督行政裁定书 / 2018) 最高法行 申 3538 号.
} 
come a right is not protected? If it is a right, the law protects it, one may argue. Reversely, as we have seen and as has been affirmed (Cao and Mannoni 2017; Mannoni and Cao 2018), the Chinese court may claim that your rights are indeed rights, but they are not right (in the sense of being correct) - and may not be protected. This creates uncertainty about the legal outcome of the court process and amplifies the discretion of the court.

Another example of this type of indeterminacy at the lexicon level is found in the Chinese law of agency, broadly defined as the relationship that arises when one person (principal) assents to another person (agent) that the agent shall act on the principal's behalf (American Law Institute, in Munday 2010: 1). In the various laws that currently regulate agency in China, such as the Common Principles of the Civil Law (MFTZ), the General Principles of Civil Law (MFZZ), and the Contract Law (HTF), two key terms appear, weituo (委托, 'to entrust') and daili (代理, 'to represent'). Due to the linguistic features of the Chinese language at the word formation level, these words combine into compound words in an opaque modifier-modified structure. Uncertainty about the meaning of the compound words arises because one cannot easily ascertain the semantic relationship that connects the modifier to the modified. For instance, daili ren (代理人; e.g. article $63 \mathrm{MFZZ)} \mathrm{literally} \mathrm{means} \mathrm{'a} \mathrm{person} \mathrm{OF} \mathrm{daili'),} \mathrm{and} \mathrm{weituo}$ ren (委托人; e.g. article $65 \mathrm{MFTZ}$ ) 'a person of weituo'; then there is weituo daili ren (委托代理人; article $163 \mathrm{MFZZ}$ ), meaning 'a person of weituo and daili': but who are these persons? Which is the principal, and which the agent? Or do these terms designate somebody else? In any less analytic language, such as Italian, these terms would be clearer. As anticipated, the degree of uncertainty may not be the same across various languages. For instance, the Italian word for principal is rappresentato - literally 'he who is represented'; the one for agent is rappresentante - literally ' $\mathrm{s} / \mathrm{he}$ who represents'. The meaning of these legal words is clearer in Italian than it is in Chinese. Although it is surely true that both for intralingual and interlingual communication one can look up these words in the legal provisions and see how they are used in context to make meaning of them, it is also true that the Chinese law use them in an unprecise and inconsistent fashion: in fact, weituo ren is also used in Article 2 of the Trust Law which transplanted the Anglo-American institute of trust - that has nothing do with agency. It seems that the Chinese tendency to translate every foreign-spoken word with Chinese characters, complicates, rather than simplifies, 
comprehension. In transplanting foreign legal notions, other languages use much clearer and more transparent strategies. For instance, as can be seen in the German and Italian Translations of the 1985 Trusts Convention, these languages have maintained English "trust", "trustor", and "trustee" as the key terms in trust law, so they cannot be confused with any other indigenous fiduciary relationship, where German and Italian are used. It is not a matter of Chinese characters, but one of imprecision. To avoid semantic indeterminacy, the Japanese language, which also uses Chinese characters, uses the agentive suffix -sha (者) at the end of the designations for the trustor, trustee and beneficiary. For instance, “trustor" is itakusha (委託者), literally meaning 's/he who entrusts' - a solution that could have, but that has not, been used by the Chinese as well, which also uses -sha (read -zhe) in many words but the above. This type of indeterminacy is unintentional, for it does not serve any purpose. When the target language is more transparent and less indeterminate than the source language, unintentional morphogrammatical indeterminacy needs to be solved interlingually by the legal translator. Thus, one uncertain term such as dailiren will be translated into a more precise term in a more transparent language, such as Italian.

It seems that although one cannot empirically measure if Chinese is vaguer than other languages, as has been argued (Cao 2018a), some lexical choices at the word formation level seem to be less transparent than others, as in the Chinese examples that I have discussed.

\subsection{Intrinsic uncertainty}

The last type of linguistic indeterminacy that we are looking at in this study is intrinsic indeterminacy. As we have seen in the taxonomy proposed earlier, this kind of uncertainty has several subtypes.

To make sense of the ordinary uncertainty in Chinese law we can use corpus linguistics. A search in ChinLaw for the most frequent words with LancsBox lists the words qita (其他) 'other', and deng (等) 'etc.' among the most relatively frequent words (having a coefficient of variation $(\mathrm{CV})$ of 0.604190 and 0.874944 , respectively, with de 的 
being the most frequent word with a CV of 0.181771$)^{3}$. Both these words create open-end lists of items that the citizens - i.e. the subjects of the law - and barristers alike can interpret one way, whilst the judge in another (see also the findings of Cao 2018a: 151-passim). This type of generality creates uncertainty in the interpretation of the law. To illustrate we can use the ChinLaw corpus. In order to provide significant examples, I set qita as my node (i.e., the word we search for in a corpus with any software specifically designed for the purpose) and retrieved its collocates (i.e., the words that most frequently appear along with it). The association measure I used is logDice, which "favour[s] collocates which occur exclusively in each other's company but do not have to be rare" (Brezina 2018: 70; see also Gablasova, Brezina, and McEnery 2017: 162-6). LogDice operates on a pre-set scale of 14 , a value that we may obtain for words that co-occur only exclusively with each other, such as zig zag in English (Gablasova, Brezina, and McEnery 2017: 164). I set a threshold at $\log$ Dice $=8.0$, and a collocate frequency higher or equal to 10; I also set a span window of 5 words right of the node, where the modified element appears (as in Chinese one says 'other materials' (qita cailiao), and cannot say 'materials other').

Figure 1: Strongest collocates of qita (其他 'other') in Chinese laws (LancsBox)

\begin{tabular}{|c|c|c|c|c|}
\hline$\nabla$ Span & \multicolumn{2}{|l|}{$0<>5$} & $\boldsymbol{\nabla}$ Statistics & $09-\log$ \\
\hline & & & \multicolumn{2}{|c|}{ 其他 } \\
\hline Index & Status & Stat $(09-\ldots$ & Collocate & Stat \\
\hline 1 & 0 & $\mathrm{R}$ & 责任人员 & $11.162154080 \ldots$ \\
\hline 2 & 。 & $\mathrm{R}$ & 直接 & $11.035458634 \ldots$ \\
\hline 3 & 。 & $\mathrm{R}$ & 给予 & $10.530683107 \ldots$ \\
\hline 4 & . & $\mathrm{R}$ & 组织 & $10.298488443 \ldots$ \\
\hline 5 & o & $\mathrm{R}$ & 依法 & $10.072645301 \ldots$ \\
\hline 6 & 。 & $\mathrm{R}$ & 有关 & $10.052078104 \ldots$ \\
\hline 7 & 0 & $\mathrm{R}$ & 的 & $9.6088101236 \ldots$ \\
\hline 8 & 10 & $\mathrm{R}$ & 旄 & $9.5202959868 \ldots$ \\
\hline 9 & 0 & R & 个人 & $9.4584416158 \ldots$ \\
\hline 10 & 。 & $\mathrm{R}$ & 有关部门 & $9.4515633741 \ldots$ \\
\hline 11 & 0 & $\mathrm{R}$ & 行政处分 & $9.4475581401 \ldots$ \\
\hline 12 & 。 & $\mathrm{R}$ & 单位 & $9.3497589088 \ldots$ \\
\hline 13 & a & IR & 行为 & $9.3283160224 \ldots$ \\
\hline 14 & o & R & 法律 & $9.2587781810 \ldots$ \\
\hline 15 & 。 & R & 事项 & $9.2420624007 \ldots$ \\
\hline 16 & 。 & $\mathrm{R}$ & 资料 & $9.2067661873 \ldots$ \\
\hline 17 & 。 & $\mathrm{R}$ & 形式 & $9.2044181844 \ldots$ \\
\hline 18 & 。 & $\mathrm{R}$ & 条件 & $9.2013064692 \ldots$ \\
\hline 19 & 。 & $\mathrm{R}$ & 应当 & $9.1902625986 \ldots$ \\
\hline 20 & 。 & $\mathrm{R}$ & 财产 & $9.1313978911 \ldots$ \\
\hline 21 & 0 & $\mathrm{R}$ & 人员 & $9.0993097059 \ldots$ \\
\hline 22 & 10 & $\mathrm{R}$ & 情形 & $9.0962153146 \ldots$ \\
\hline 23 & 0 & $R$ & 机构 & $8.9968015454 \ldots$ \\
\hline 24 & 。 & $\mathrm{R}$ & 或者 & $8.9854009129 \ldots$ \\
\hline 25 & 。 & $\mathrm{R}$ & 警告 & $8.9697508773 \ldots$ \\
\hline 26 & 。 & $\mathrm{R}$ & 经营者 & $8.9508417187 \ldots$ \\
\hline 27 & 0 & $R$ & 在 & $8.9503270776 \ldots$ \\
\hline 28 & lo & $\mathrm{R}$ & 文件 & $8.8586803110 \ldots$ \\
\hline
\end{tabular}

\footnotetext{
${ }^{3}$ Although these figures may change while the corpus enlarges, they should not be expected to change significantly, due to the corpus being almost finished.
} 
The above Figure 1 shows the first twenty-eight strongest collocates of my node, qita. In the figure, I highlighted the collocates fangshi (方式 'method, mean, way'), xingwei (行为 'act, action'), qingxing (情形 'circumstances'), and wenjian (文件 'documents'), for it is useful to discuss them here. The implications of the presence of these collocates of qita may be that it is up to the court to decide which are, in more concrete terms, the other methods, actions, circumstances, or documents that have to fall within the scope of the relevant provisions. By right clicking on any of these words, it is possible to see the instances when the selected collocate and the node appear together in the corpus. For instance, by right-clicking on fangshi, I found the following Article 15 of the National Anthem Law (my emphasis):

\title{
“第十五条 在公共场合, 故意篡改国歌歌词、曲谱，以歪曲、 贬损方式奏唱国歌, 或者以其他方式侮辱国歌的, 由公安机矢处 以警告或者十五日以下拘留; 构成犯罪的, 依法追究刑事责任。
}

\begin{abstract}
Article 15 Intentionally distorting the lyrics or the rhythm of the national anthem in a public place [...], or dishonouring the national anthem in other ways results in a warning from the Office of Public Safety or in detention up to fifteen days. In the event that this constitutes a crime, the offender shall bear criminal liability."
\end{abstract}

While of course we may have an idea of what "intentionally distorting the lyrics" means, it is hard to understand what the concrete circumstances in which one may be held criminally liable for "dishonouring the national anthem in other ways" are, and punished accordingly. This is open to interpretation, either by the citizens, the police, or the court.

An often-mentioned ambiguous Chinese word is quan, that we have seen earlier. It means 'authority', 'privilege', 'power', and 'rights'. They are not synonyms in the legal language. Although these meanings are often equally possible in the legal context, sometimes even in the same phrase, they are not the same (Cao 2018b; Mannoni 2018; Yang Chao 2018). The differences between them are especially palpable in cross-lingual communication, when one has to translate ambiguous legal words in a less ambiguous language. Whilst it is true that " $[\mathrm{t}] \mathrm{he}$ legal translator is not the lawyer [...] and must always resist the temptation to clarify or make a word more precise" (Cao 2007b, 81), this is not possible when the target language requires more clarity than the source. As is known, translated texts tend to be clearer and less 
vague than source texts, and are thus translated accordingly. For instance, since no English legal word is as ambiguous as quan is in Chinese, whichever its translation, the result will be clearer, and so will the legal meaning. In ChinLaw, the phrase you quan 'to have quan' has 1,542 occurrences distributed in 306 texts out of the 466 texts that so far constitute the corpus. How do we translate the phrase? 'To have the right', 'the privilege', or else what? No univocal answer can be given.

To illustrate transparent indeterminacy, we can use a top-down approach and search for any transparently uncertain word, such as jishi (及时), in ChinLaw, and see if it appears in the data and how it is used. Jishi means 'timely, promptly', and is imprecise in the legal context: what does the word mean in practice? How many seconds, minutes, hours have to pass so that one can be judged, say, to have acted in a timely fashion, or accused of the contrary? A search of jishi retrieves 1,176 distributed in around half of the texts of which the corpus is composed (i.e. 272/466). A search for the collocates of jishi in ChinLaw, using the same settings indicated above, but this time searching for them both left and right of the node, finds that the most frequent collocates of jishi include baogao (报告 'to report'; LogDice: 10.55) and tongzhi (通知 'to notify'; LogDice: 10.49) right of the node, and the performative yingdang (应当 'shall') ahead of it. These suggest that jishi may mostly occur in phrases such as 'to promptly report', 'to promptly inform', and 'shall promptly [do something]'. Figure 2 below is a graphical representation of the collocates of jishi obtained with the GraphColl function of LancsBox that better illustrates the bond between the node and its collocates. 
Figure 2. Illustration the collocates of jishi (及时 'promptly') in Chinese laws (LancsBox)

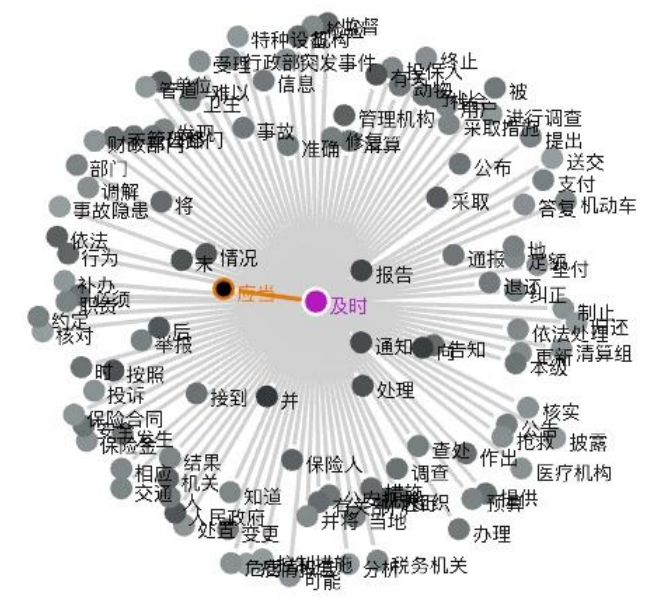

The closer the collocates to the node, the stronger their bond with it. As can be seen, yingdang (coloured in orange), a legal performative (Cao 2018b), is particularly close to jishi. For the purpose of this study, it is important to see how legal meaning varies due to its semantic indeterminacy. So, I right clicked on yingdang and retrieved instances of it together with jishi. I found various provisions, including the following Article 33 of the Criminal Procedure Law (my emphasis): “第三十三条 $[\ldots]$ 犯罪嫌疑人、被告人在押期间要求委托辩护人
的, 人民法院、人民检察院和公安机矢应当及时转达其要求。[...]

辩护人接受犯罪嫌疑人、被告人委托后, 应当及时告知办理案件 的机矢。

Article 33 [...] If a suspect or a defendant asks to be represented by a defense lawyer, the People's Court, the People's Prosecutor's Office, and the Department for Public Safety shall promptly notify the request. $[\ldots]$

After the defense lawyer has been instructed by the suspect or the defendant, the attorney shall promptly inform the competent authority for the case."

As can be seen, it is unclear what the time limits indicated in the provisions are. One can have a sense of what the word for 'promptly' means in the context, say, 24 hours, but if we keep adding even just 
a couple of minutes to that time, we will end up in any longer period of time that the competent authority may then deem as late - and hence invalid.

Finally, here we see the last type of indeterminacy that I have identified in the taxonomy proposed earlier, i.e., extravagant indeterminacy. When ascertaining the meaning of extravagantly indeterminate wordings, factors that differ in nature and that are not measurable have to be considered. This makes the word or phrase obscure in meaning, and thus particularly open to interpretation. When extravagant words are in key parts of the law, such as the Constitution, judicial discretion is high, as no specific provision limits the extent of their interpretations. To illustrate we can use the extravagantly uncertain terms shehui zhixu (社会秩序 'social order'), shehui hexie (社会和谐 'social harmony'), and shehui wending (社会稳定 'social stability'). They are key terms in the Chinese culture and have no univocal definition in scholarship, let alone in Chinese law (see e.g. Guo and Blanchard 2008). They are used in many provisions where the law indicates that a certain law is enacted in order to maintain them, or that nobody shall disturb them. For instance, Articles 36 of the Constitution provides the following (my emphasis):

\section{“第三十六条 任何人不得利用宗教进行破坏社会秩序、损害公民 身体健康、妨碍国家教育制度的活动。宗教团体和宗教事务不受 外国势力的支配。}

Article 36. Nobody shall use religion to disturb the social order (shehui zhixu), harm the health of citizens, obstruct the educational activities of the State. Religious groups and affairs do not receive the control of foreign powers."

Since no truth of the matter can be established as to whether someone is disturbing the social order with their religious activity, this type of linguistic uncertainty creates uncertainty about the law. The Chinese people seem to be particularly afraid of these wordings, for they know that the accusation of disturbing social order et similia can be applied to an indefinite number of circumstances by the police or the court. Linguistically, this results in metonyms, by which some of these words stand for their effects. For instance, the word 'harmony' (hexie) can be used to mean that censorship has been applied, as in 'has been harmonised' (bei hexie le 被和谐了). Additionally, since héxié ('harmony') is a quasi-homophone of the word for 'river crab' (héxiè), 
sometimes 'has been river crabbed' (bei hexie le 被河蟹了) is used as an euphemism to indicate that censorship has been applied by the Chinese government (Link and Qiang 2013: 251). This also shows that the effects of these vague words are particularly clear to the Chinese, who are scared of them.

In 2019, a case of domestic violence was submitted to a court in Chengdu: "The beatings were so brutal that Dong Fang (not her real name) was left partially deaf, and her daughter needed three stitches in her hand." (The Economist 2019). Thanks to the enforcement of the first national law against domestic violence, Mrs Dong did obtain a restraining order from the Chinese court, but her petition for divorce was rejected at first instance (although it was accepted at second instance; see Hubei Luntan Wang 2019). The case caught the media attention, both in China and abroad. The decision at first instance may echo the intentions behind the wordings of the first article of the law against domestic violence, which provides that

\section{“第一条为了预防和制止家庭暴力, 保护家庭成员的合法权益, 维护平等、和睦、文明的家庭矢系, 促进家庭和谐、社会稳定, 制定本法。}

Article 1 This law is enacted in order to protect the hefa quanyi of the family members, to maintain equality, harmony, and civility in family relationships, and to improve family harmony and social stability (shehui wending)."

(my emphasis)

If 'social stability' is interpreted in the Confucianist acceptation of family-oriented society, then divorce may be more difficult to obtain than if the phrase is interpreted differently (see D'Attoma 2013). The interpretation of such an indeterminate term such as 'social stability' affects the overall interpretation of a statute, and, ultimately, the way it is enforced.

In some cases, a vague phrasing 'disturbing social order' has been reportedly used by the police to falsely accuse somebody, when the accusations seem to hide a more ample agenda. That was the case of two Uyghur men, belonging to a Turkic Muslim diaspora community living in the Xinjiang Region in China, recognised as one of the fiftysix ethnic groups of the country besides the Han (汉), the major Chinese group. In the following excerpt from a report by the Human Rights 
Watch, which has accused the Chinese government of carrying out repressive policies against the Uyghurs (2018, Summary), we can note that the phrasing was used in the accusations that policemen made to two Uyghur men:

"The [Chinese] police also accused the two men who were held in detention centers of "disturbing social order," "endangering state security," and "harboring terrorists." However, the police did not provide evidence of criminal behavior."

(Human Rights Watch 2018: 29; my emphasis)

It is noted that I could not find and, hence, could not consider the Chinese version of the police report. Based on the Human Rights Watch report, 'disturbing social order' here seems to be used by the police to falsely accuse and arrest the two Uyghurs. Under this interpretation, the use of the wording by the Chinese police may not be intentional, but its presence in the Chinese law may be, allowing for a multitude of interpretations and applications, and leaving space to judicial discretion.

\section{Conclusions}

This study has proposed a taxonomy of linguistic indeterminacy and has exemplified its various types with examples from the Chinese statutes and court decisions. The linguistic data used in this study has been retrieved from various sources, including statutes and court decisions, and has been analysed by means of different methods, both quantitatively and qualitatively. This study has found that different types of indeterminacy have different implications, and when the language of the law is particularly vague, those who enforce it have ample freedom of interpretation. Additionally, the Chinese lexicon as used in Mainland China seems to be formed in a more obscure fashion than it is in other languages.

It is important that we do not draw a hasty conclusion from the above and believe that China has the vaguest laws and language. For such a proposition to be maintained, extensive quantitative data analysis has to be carried out in a comparative perspective, comparing the Chinese data with those of other countries. This kind of analysis 
may be difficult or even practically impossible to carry out, for indeterminacy and vagueness alike may not be empirically measurable. In the absence of such research, the argument put forward in this study cannot go beyond the simple but fundamental principle that the more uncertain the language, the more uncertain the law.

On January 1, 2021, circa one thousand five hundred years after the Corpus Iuris Civilis was compiled, China will enact its first Civil Code (Minfa Dian 民法典). Expectations on it are sky-high, and so are the demands by the international community: China is expected to better protect the rights, including human rights, of its citizens. This, by just merging into one code different laws that already exist as of now. In linguistic terms, a precise and less uncertain language can improve the understanding of the law and diminish the gap between law in the books and law in action. Nevertheless, as we have seen, not everything is about language: even more is about the will behind it. For starters, Article 1 of the new Civil Code provides that the code is enacted to protect the lawful rights and interests (hefa quanyi) of the civil subjects, subordinately to the Constitution ${ }^{4}$, whose Article 15, in turn, stipulates that "The State forbids any organisation and individual to disturb the socioeconomical order (shehui jingji zhixu)" ${ }^{\prime 5}$. We will see what the combination of these two provisions means in legal terms.

\section{Bibliography}

Alston, William P. 1964. Philosophy of Language. Upper Saddle River: Prentice-Hall.

Antia, Bassey Edem. 2007. Indeterminacy in Terminology and LSP: Studies in Honour of Heribert Picht. Amsterdam/Philadelphia: John Benjamins Publishing.

Asgeirsson, Hrafn. 2015. On the Instrumental Value of Vagueness in the Law. Ethics 125 (2): 425-48.

Benney, Jonathan. 2013. Defending Rights in Contemporary China. Oxon: Routledge.

Brezina, Vaclav. 2018. Statistics in Corpus Linguistics: A Practical

\footnotetext{
4 第一条为了保护民事主体的合法权益,调整民事关系,维护社会和经济秩序,适应 中国特色社会主义发展要求,弘扬社会主义核心价值观,根据宪法,制定本法。

5 第十五条 [...] 国家依法禁止任何组织或者个人扰乱社会经济秩序。
} 
Guide. Cambridge/New York: Cambridge University Press.

Brezina, Vaclav, Matt Timperley, and Tony McEnery. 2018. LancsBox v. 4.x [Software]. http://corpora.lancs.ac.uk/lancsbox.

Cao, Deborah. 2004. Chinese Law: A Language Perspective. Aldershot: Ashgate.

Cao, Deborah 2007a. Inter-Lingual Uncertainty in Bilingual and Multilingual Law. Journal of Pragmatics 39: 69-83.

Cao, Deborah. 2007b. Translating Law. Clevedon: Multilingual Matters.

Cao, Deborah. 2017. On the Universality of "Rights": Absence and Presence of "Rights" in the Chinese Language. Intercultural Pragmatics 14: 277-92.

Cao, Deborah. 2018a. Is the Chinese Legal Language More Ambiguous and Vague?. In Chinese Language in Law - Code Red, 147-70. Lanham: Lexington Books.

Cao, Deborah. 2018b. 'Legal Speech Acts and Chinese Legal Performatives'. In Chinese Language in Law-Code Red, 11746. Lanham: Lexington Books.

Cao, Deborah. 2018c. "Linguistic and Cultural Meanings of "Rights" in Chinese'. In Chinese Language in Law - Code Red, 101-16. Lanham: Lexington Books.

Cao, Deborah, and Michele Mannoni. 2017. 'Are There "Illegal Rights" in Chinese Law? On the Meanings of Feifa Quanyi'. The Chinese Journal of Comparative Law - Oxford Univ. Press 5 (1): 190-204.

Chang, Hui-Ching. 1999. The "well-Defined" Is "Ambiguous" Indeterminacy in Chinese Conversation. Journal of Pragmatics 31: 535-56.

Codice Civile [Civil Code of Italy]. 1942. https://www.brocardi.it/codice-civile/.

D’Attoma, Sara. forthcoming. 'Bainian (Bu) Haohe 百年(不)好合! One Hundred Years of Marital Unhappiness! Analysis of Divorce Proceedings Involving Domestic Violence and Personal Protection Order System in China'. Journal of Comparative Law (forthcoming).

D'Attoma, Sara. 2013. To Trust and to Love Each Other: Forms of Mediation in Contested Divorce Cases. In Family in Asian Cultures and Societies, ed. Maria Angelillo, 5: 269-82. Rome: Accademia Ambrosiana - Bulzoni Editore.

Deignan, Alice. 1999. 'Corpus-Based Research into Metaphor'. In 
Michele Mannoni: On the Forms and Thorns of Linguistic...

Researching and Applying Metaphor, ed. Lynne Cameron and Graham Low, 177-99. Cambridge: Cambridge University Press.

Deignan, Alice. 2005. Metaphor and Corpus Linguistics. Amsterdam/Philadelphia: John Benjamins.

Endicott, Timothy A. O. 2000. Vagueness in Law. Oxford: Oxford University Press.

Endicott, Timothy A. O. 2011. The Value of Vagueness. In Philosophical Foundations of Language in the Law, ed. Andrei Marmor and Scott Soames. Oxford: Oxford University Press.

'Falü Fagui Shujuku 法律法规数据库 (Digital Repository of Laws and

Regulations)'. n.d. http://search.chinalaw.gov.cn/search2.html.

Fu, Junwei. 2011. Modern European and Chinese Contract Law: A

Comparative Study of Party Autonomy. Alphen aan den Rijn:

Kluwer Law International.

Gablasova, Dana, Vaclav Brezina, and Tony McEnery. 2017.

Collocations in Corpus-Based Language Learning Research.

Language Learning 67 (S1): 155-79.

Guo, Sujian, and Jean-Marc F. Blanchard, eds. 2008. Harmonious

World and China's New Foreign Policy. Plymouth: Lexington Books.

Hart, Herbert Lionel Adolphus. 2012. The Concept of Law. Ed.

Penelope A. Bulloch and Joseph Raz. $3^{\text {rd }}$ ed. Croydon: Oxford University Press.

He Shurui 何书睿 (ed.). 2015. Zhongguo Shoubu Fanjiabao Fa Tongguo: Mingque Dingyi Jiabao Xingwei Tongju Ye Naru 中 国首部反家暴法通过: 明确定义家暴行为 同居也纳入 [China passed first national law against domestic violence: It clearly defines domestic violence, including cohabitation], December 27 2015.

http://www.guancha.cn/FaZhi/2015_12_27_346130.shtml (accessed July 31, 2019)

Hoijer, Harry. 1954. The Sapir-Whorf Hypothesis. Language in Culture, Proceedings of a Conference ... reprinted in Morton H. Fried, ed., Readings in Anthropology, Vol. 1: 219-31. (New York: Crowell, 1969: 92-105).

Hubei Luntan Wang 湖北论坛网. 2019. Nü Jiaoshi Bwei Jiabao Zhi Ermo Chuankong, Fayuan Buzhun Lihun! Guansi Da Le 2 Nian, Zhongyu ... 女教师被家暴致耳膜穿孔，法院却不准离婚！ 官司打了 2年，终于... [A female teacher's left eardrum was 
damaged due to family violence, but the court did not grant divorce! After 2-year proceedings, at the end...]', November 29, 2019. http://www.hbbbs.cc/wap/29692-1.html (accessed June 2, 2020).

Human Rights Watch. 2018. "Eradicating Ideological Viruses": China's Campaign of Repression against Xinjiang's Muslims'. United States of America: Human Rights Watch. https://www.hrw.org/report/2018/09/09/eradicatingideological-viruses/chinas-campaign-repression-againstxinjiangs (accessed May 29, 2020).

Keil, Geert, and Ralf Poscher, eds. 2016. Vagueness and Law: Philosophical and Legal Perspectives. Oxford: Oxford University Press.

Li, Charles N., and Sandra A. Thompson. 1989. Mandarin Chinese: A Functional Reference Grammar. California: University of California Press.

Link, Perry, and Xiao Qiang. 2013. From "Fart People" to Citizens. In Will China Democratize?, edited by Andrew J. Nathan, Larry Diamond, and Marc F. Plattner, 249-55. Baltimore: The Johns Hopkins University Press.

Mannoni, Michele. 2018. Hefa Quanyi: More than a Problem of Translation. Linguistic Evidence of Lawfully Limited Rights in China. International Journal for the Semiotics of Law - Revue Internationale de Sémiotique Juridique 32 (1): 29-46.

Mannoni, Michele. 2019. Wrong Rights: On Chinese "Improper Rights and Interests" (Bu Zhengdang Quanyi). In Legal Translation (Studies) as a Challenge / Herausforderungen an Das Rechtsübersetzen. Forum Für Fachsprachen-Forschung (FFF). Berlin: Frank \& Timme.

Mannoni, Michele, and Deborah Cao. 2016. On the Meaning of Feifa Quanyi in Chinese Legal Language: A Semiotic and Corpus Analysis. Linguistics and the Human Sciences 12 (2-3): 177203.

Marmor, Andrei. 2014. Varieties of Vagueness in the Law. In The Language of Law, 85-105. Oxford: Oxford University Press.

Ministry of Commerce of the People's Replublic of China. 1994. Law of the People's Republic of China on the Protection of the Rights and Interests of Consumers. http://english.mofcom.gov.cn/aarticle/lawsdata/chineselaw/20 0211/20021100053545.html (accessed May 27, 2020). 
Munday, Roderick. 2010. Agency: Law and Principles. Oxford: Oxford University Press.

Rogers, Margaret. 2007. Indeterminacy in Technical Translation. In Lexical Chains in Technical Translation. A Case Study in Indetermincy. Ed. Bassey Edem Antia, 15-35. Amsterdam/Philadelphia: John Benjamins Publishing.

Schane, Sanford. 2002. Ambiguity and Misunderstanding in the Law. Thomas Jefferson Law Review 25 (1): 167-93.

Schneider, Carl E. 2007. Void for Vagueness (at Law). The Hastings Center Report 37 (1): 10-1.

Shuy, Roger W. 2008. Fighting over Words: Language and Civil Law Cases. Oxford: Oxford University Press.

Shuy, Roger W. 2017. Deceptive Ambiguity by Police and Prosecutors. Oxford Studies in Language and Law. New York: Oxford University Press.

Simonnæs, Ingrid. 2007. Vague Legal Concepts: A Contradictio in Adjecto?. In Indeterminacy in Terminology and LSP: Studies in Honour of Heribert Picht. Ed. Bassey Edem Antia, 119-34. Amsterdam/Philadelphia: John Benjamins Publishing.

Solan, Lawrence M., and Gales Tammy. 2016. Finding Ordinary Meaning in Law: The Judge, the Dictionary or the Corpus?. International Journal of Legal Discourse 1 (2): 253-76.

The Economist. 2019. In China, Courts Deny Women Divorces in the Name of "Social Harmony" - No Escape, October 12, 2019, sec. China. https://www.economist.com/china/2019/10/12/inchina-courts-deny-women-divorces-in-the-name-of-socialharmony.

Translations of the 1985 Trusts Convention. 1985. https://www.hcch.net/en/publications-andstudies/details4/?pid=5991\&dtid=21 (accessed May 28, 2020). Triebel, Volker. 2009. Pitfalls of English as a Contract Language. In Translation Issues in Language and Law. Ed. Frances Olsen, Alexander Lorz, and Dieter Stein, 147-81. Hampshire: Springer.

Volokh, Eugene. 2015. Judges and "Corpus Linguistics". The Washington Post, August 17, 2015. https://www.washingtonpost.com/news/volokhconspiracy/wp/2015/08/17/judges-and-corpuslinguistics/?utm_term $=.7785 f 493140 \mathrm{c}$ (accessed August 28, 2017). 
Waldron, Jeremy. 2011. Vagueness and the Guidance of Action. In Philosophical Foundations of Language in the Law. Eds. Andrei Marmor and Scott Soames, 58-82. Oxford: Oxford University Press.

Wong, Kam-Fai, Wenjie Li, and Ruifeng Xu. 2009. Introduction to Chinese Natural Language Processing. S.1.: Morgan \& Claypool Publishers.

Yang Chao 杨焯. 2018. Qingmo Xifang Faxue Gainian de Chuanbo Yu Hanzhi Fuhao de Xingcheng: Yi "Wanguo Gongfa" Zhong de “Right” Wei Kaocha Duixiang 清末西方法学概念的传播与 衍指符号的形成一以《万国公法》中的“Right”为考察对 象 [On the diffusion of Western legal notions during the lateQing and the formation of a super-sign: investigating the word "right" in the Chinese translation of "Elements of International Law" ']. In Falü Fanyi Yanjiu 法律翻译研究 Legal Translation Studies. Ed. Qu Wensheng 屈文生, 120-74. Shanghai 上海: Shanghai Renmin Chubanshe 上海人民出版 社.

Zhongguo Caipan Wenshu Wang 中国裁判文书网 [China Judgements Database]. Corpus. http://wenshu.court.gov.cn.

Zhonghua Renmin Gongheguo Guoge Fa 中华人民共和国国歌法 [National Anthem Law of the People's Replublic of China]. 2017. http://www.gov.cn/guoqing/201709/04/content_5222515.htm.

Zhonghua Renmin Gongheguo Hetong $\mathrm{Fa}$ 中华人民共和国合同法 [Contract Law of the People's Republic of China]. 1999. http://www.npc.gov.cn/wxzl/wxzl/2000-

12/06/content_4732.htm.

Zhonghua Renmin Gongheguo Jiating Baolifa 中华人民共和国反家 庭暴力法 ["Anti-Domestic Violence Law of the People's Republic of China"]. 2016. http://www.gov.cn/zhengce/201512/28/content_5029898.htm.

Zhonghua Renmin Gongheguo Minfa Dian (Cao'an) 中华人民共和国 民法典 (草案) [Civil Code of the People's Republic of China (Draft)]. 2021.

https://npcobserver.files.wordpress.com/2019/12/civil-codedecember-16-unofficial-draft.pdf.

Zhonghua Renmin Gongheguo Minfa Tongze 中华人民共和国民法通 则(2009修正) ['Common Principles of the Civil Law of the People's Republic of China (2009 Amendment)']. 1987. 
Michele Mannoni: On the Forms and Thorns of Linguistic...

http://www.npc.gov.cn/wxzl/wxzl/2000-

12/06/content_4470.htm.

Zhonghua Renmin Gongheguo Minfa Zongze 中华人民共和国民法总 则 ['General Principles of Civil Law of the People's Republic of China' Aka 'General Part of the Civil Code of the People's Republic of China']. 2017. http://www.chinacourt.org/law/detail/2017/03/id/149272.shtm 1.

Zhonghua Renmin Gongheguo Xianfa (1982) 中华人民共和国宪法 (1982) (1982 Constitution of the People's Republic of China, 2018 Amendment). n.d. www.npc.gov.cn.

Zhonghua Renmin Gongheguo Xingshi Susong Fa 中华人民共和国形 事诉讼法 (Criminal Procedure Law of the People's Republic of China). 1979. www.npc.gov.cn.

Zhonghua Renmin Gongheguo Xintuo Fa 中华人民共和国信托法 [Trust Law of the People's Republic of China]. 2001. http://www.npc.gov.cn/wxzl/wxzl/200105/30/content_136770.htm.

Zhonghua Renmin Gongheguo Zhongyang Renmin Zhengfu 中华人民 共和国中央人民政府 [The Central People's Government of the People's Republic of China]. http://www.gov.cn/flfg/fl.htm. 